\title{
TINJAUAN YURIDIS PERTANGUGNJAWABAN PRESIDEN DALAM PELAKSANAAN HAK KONSTITUSIONAL SESUDAH AMANDEMEN UNDANG-UNDANG DASAR NEGARA REPUBLIK INDONESIA TAHUN 1945
}

\author{
MEYDIANTO MENE \\ Mene080809@gmail.com \\ Universitas Ekasakti
}

\begin{abstract}
Abstrak: In the Constitution of the Republic of Indonesia Year 1945 stipulates that Indonesia is adopting a presidential system in the administration of the State. The consequence of this system, as stipulated in Article 4, paragraph 1 of the 1945 Constitution, that the president acts as head of government. In addition, implied by reference in Article 10 to Article 15 of the 1945 Constitution, the president also acted as Head of State, of the provisions of the president has a great power. In the 1945 Constitution besides regulating the system of government also regulates the powers of the president who is usually known as the Right Prerogative but the authors have called for Constitutional Rights. Authorizations are set out in Articles 10, 11, 12, 13, 14 and Article 15 of the 1945 Constitution existence of the special session is not mentioned explicitly in the 1945 Constitution Article 2 paragraph (2) of the 1945 Constitution states that the Assembly convene at least once in five years, however Tap. III / 1978 set for the existence of the special session (SI) to hold the president in the middle of his term.
\end{abstract}

Keyword: Contitusion, Liability

Abstrak: Dalam Undang-Undang Dasar Negara Republik Indonesia Tahun 1945 ditetapkan bahwa Indonesia mengadopsi sistem presidensial dalam administrasi Negara. Konsekuensi dari sistem ini, sebagaimana diatur dalam Pasal 4 ayat 1 UUD 1945, bahwa presiden bertindak sebagai kepala pemerintahan. Selain itu, tersirat dengan referensi dalam Pasal 10 hingga Pasal 15 UUD 1945, presiden juga bertindak sebagai Kepala Negara, dari ketentuan presiden memiliki kekuatan yang besar. Dalam UUD 1945 selain mengatur sistem pemerintahan juga mengatur kekuasaan presiden yang biasanya dikenal dengan Hak Prerogatif tetapi penulis telah menyerukan Hak Konstitusional. Otorisasi yang diatur dalam Pasal 10, 11, 12, 13, 14 dan Pasal 15 UUD 1945 tentang keberadaan sidang khusus tidak disebutkan secara eksplisit dalam UUD 1945 Pasal 2 ayat (2) UUD 1945 menyatakan bahwa Majelis bersidang. setidaknya sekali dalam lima tahun, namun Ketuk. III / 1978 mengatur keberadaan sesi khusus (SI) untuk menahan presiden di tengah masa jabatannya.

Kata kunci: Konstitusi, Pertanggungjawaban

\section{A. Pendahuluan}

Undang-Undang Dasar Negara Republik Indonesia Tahun 1945 (UUD 1945) mengatur bahwa Indonesia menganut sistem presidensial dalam penyelenggaraan Negara. Konsekuensi dari sistem ini, sebagaimana yang diatur dalam Pasal 4 ayat 1 UUD 1945, bahwa presiden bertindak sebagai Kepala pemerintahan. Selain itu, secara tersirat dengan merujuk dalam Pasal 10 hingga Pasal 15 UUD 1945, presiden juga bertindak sebagai Kepala Negara, dari ketentuan tersebut presiden memiliki kekuasaan yang besar. Namun, ini tidak berarti kekuasaan presiden bersifat terbatas. Karena 88 Lembaga Penelitian dan Penerbitan Hasil Penelitian Ensiklopedia $\quad$ E-ISSN: 2657-0300 
dalam penyelenggaraan pemerintahan, Indonesia juga mengenal sistem pemisahan kekuasaan dalam bentuk lunak atau dalam kata lain Indonesia mengamalkan sistem pembagian kekuasaan di antara lembaga-lembaga Negara. Misalnya sebagai Kepala pemerintahan presiden mengajukan Rancangan Undang-Undang kepada DPR dan membahasnya bersama-sama dengan lembaga Legislatif.

Jimly Asshidiqie (2002: 42-43) menyebut model keempat yang banyak pula dipraktekkan di Negara-negara di dunia, yaitu model Perancis yang memilki model sendiri yang bersifat campuran atau hybrid system. Pada umumnya Negara-negara jajahan Perancis di Afrika menganut sistem campuran ini. Di satu segi ada pembedaan antara Kepala Negara dan Kepala pemerintahan tetapi Kepala negaranya adalah presiden yang dipilih dan bertanggungjawab kepada rakyat secara langsung seperti dalam sistem presidensial. Sedangkan Kepala pemerintahannya di satu segi bertanggungjawab kepada presiden tetapi segi lain dia di angkat karena kedudukannya sebagai pemenang pemilu yang menduduki kursi parlemen dank arena itu juga bertanggungjawab kepada parlemen. Kecenderungan penerapan sistem pemerintahan campuran baik dalam model hybrid sistem ala Perancis atau collegial sistem ala Swiss, timbul karena kesadaran bahwa dalam sistem presidensial atau parlementer selalu saja ditemukan adanya kelemahan-kelemahan di samping kelebihan bawaan yang dimiliki masing-masing.

UUD 1945 selain mengatur mengenai sistem pemerintahan juga mengatur mengenai kekuasaan presiden yang biasanya dikenal dengan istilah Hak Prerogatif tapi penulis menyebutnya dengan istilah Hak Konstitusional. Kewenangan-kewenangan ditetapkan dalam Pasal-Pasal 10, 11, 12, 13, 14 dan Pasal 15 UUD 1945 biasanya dikaitkan dengan kedudukan presiden sebagai Kepala Negara. Pasal 11 mengatur mengenai kewenangan presiden dengan persetujuan DPR menyatakan perang dan damai dan membuat perjanjian dengan Negara lain. Pasal 12 berkenaan dengan kewenangan menyatakan keadaan bahaya. Pasal 13 berkenaan dengan pengangkatan duta dan konsul dan menerima duta Negara lain. Pasal 14 mengenai pemberian grasi dan rehabilitasi serta pemberian amnesty dan abolisi dan Pasal 15 mengenai pemberian gelar, tanda jasa, dan tanda kehormatan.

Prosedur pelaksanaan Sidang Istimewa untuk meminta pertanggungjawaban presiden dimuat dalam Ketetapan MPR No. III/MPR/1978 tentang Kedudukan dan Hubungan Tata Kerja Lembaga Tertinggi Negara dengan/atau Antar-LembagaLembaga Tinggi Negara. Di dalam Ketetapan MPR itu, disebutkan adanya dua macam pertanggungjawaban presiden, yaitu pertanggungjawaban yang diberikan di hadapan Sidang Umum MPR pada akhir masa jabatan presiden dan tanggung jawab secara khusus yang diberikan di hadapan Sidang Istimewa MPR.

Sebenarnya, masih ada persoalan mendasar dalam ketentuan tersebut. Pertama, yaitu kenyataan bahwa UUD 1945 sendiri sebenarnya tidak mengatur secara eksplisit mengenai adanya prosedur pertanggungjawaban presiden kepada MPR. Walau demikian, Penjelasan UUD 1945 memang memuat pernyataan bahwa "Presiden yang diangkat oleh Majelis, tunduk dan bertanggung jawab kepada Majelis." Prinsip inilah yang kemudian dijadikan dasar dalam pembuatan Tap. III/1978 tersebut. Sebagai perbandingan, dalam UUD RIS 1949 dan UUDS 1950 yang mengandung sistem pemerintahan parlementer, soal pertanggungjawaban presiden kepada lembaga legislatif dimuat dengan jelas. Kedua, pada dasarnya sistem pertanggungjawaban eksekutif hanya dikenal dalam sistem parlementer atau sistem semi-parlementer, tidak dalam sistem presidensial. Sebab, orientasi utama sistem pemerintahan presidensial adalah membentuk pemerintahan yang stabil dalam waktu tertentu (fixed term of E-ISSN: 2657-0300 Lembaga Penelitian dan Penerbitan Hasil Penelitian Ensiklopedia $\quad 89$ 
office). Di samping itu, sistem pemisahan kekuasaan secara tegas dalam tataran kelembagaan yang berusaha diterapkan oleh sistem presidensial berimplikasi pada tidak terjadinya peleburan antara lembaga eksekutif dan legislatif.

\section{B. Metodologi Penelitian}

Penulisan ini merupakan penelitian yang bersifat deskriptif, adapun metode pendekatan ini dilakukan dengan pendekatan Yuridis Normatif. Pendekatan Yuridis Normatif adalah metode penelitian Hukum yang dilakukan dengan meneliti bahan pustaka, melakukan sinkronisasi perundang-undangan secara vertikal dan horizontal, penemuan asas hukum yang terkait dengan pengaturan mengenai presiden dalam praktek penyelenggaraan pemerintah di Indonesia.

\section{Hasil dan Pembahasan}

Pada periode setelah perubahan UUD 1945, kekuasaan Presiden sebagai pemegang kekuasaan eksekutif sudah mulai berkurang, banyak ketentuan UUD 1945 yang pada mulanya memberikan kewenangan yang cukup besar terhadap Presiden dirubah. diantaranya: 1) Pasal 5 ayat (1) tentang kekuasaan Presiden untuk membentuk undang-undang dirubah menjadi Presiden berhak mengajukan rancangan undangundang kepada Dewan Perwakilan Rakyat; 2) Pasal 20 ayat (1), setelah perubahan memberikan kewenangan kepada DPR untuk membentuk undang-undang. Jadi, pada periode ini kekuasaan membentuk undang-undang bergeser dari semula berada di tangan Presiden, setelah perubahan beralih ke tangan DPR; 3) Pasal 6 mengalami beberapa penambahan, diantaranya Pasal 6A ayat (1) yang mneyatakan bahwa Presiden dan Wakil Presiden dipilih dalam satu paket secara langsung oleh rakyat; dan 4) Pasal 7 tentang masa jabatan Presiden dirubah dengan ketentuan bahwa Presiden hanya dapat dipilih kembali dalam jabatan yang sama, hanya untuk satu kali masa jabatan. Hal ini akan lebih menjamin rotasi kepemimpinan yang teratur.

Melalui perubahan UUD 1945, Presiden tidak lagi sebagai mandataris MPR yang tunduk dan bertanggungjawab kepadanya, Presiden tidak lagi memiliki kekuasaan membentuk undang-undang. Karena dipilih secara langsung oleh rakyat maka Presiden memiliki legitimasi yang kuat, ia tidak dapat diberhentikan oleh DPR bahkan tidak diberhentikan oleh MPR, kecuali bila terbukti melakukan pelanggaran hukum sebagaimana ditentukan dalam Pasal 7A UUD NRI 1945.

Menurut Jimly Asshiddiqie (2007: 127), bahwa setelah dilakukannya perubahan terhadap UUD 1945, maka secara konseptual UUD 1945 dapat dikatakan telah secara murni menganut sistem pemerintahan presidensiil, dengan beberapa indikator, antara lain: 1) Presiden dan Wakil Presiden merupakan satu institusi penyelenggaraan kekuasaan eksekutif; dan 2) Pengisian jabatan Presiden dan Wakil Presiden dilakukan melalui pemilihan umum secara langsung oleh rakyat (direct democracy). Presiden tidak bertanggungjawab kepada MPR kecuali jika ada tuntutan dari DPR kepada Mahkamah Konstitusi (MK) tentang adanya pelanggaran hukum dan konstitusi yang dilakukan oleh Presiden. Apabila tuntutan tersebut dikuatkan oleh MK dalam suatu keputusan, maka DPR dapat melanjutkan tuntutan pemberhentian Presiden kepada MPR.

Menelaah pola hubungan antara legislatif dan eksekutif menurut UUD NRI 1945, dari sudur pandang Arend Lijphart, menunjukkan adanya pemisahan kekuasaan di dalam sistem presidensiil, meskipun dalam UUD NRI 1945 belum secara konsisten 
dilakukan, sebab kekuasaan membentuk Undang-undang berada di tangan DPR (Pasal 20 ayat 1 ), tetapi pada ayat berikutnya menegaskan bahwa setiap rancangan undangundang dibahas oleh DPR dan Presiden untuk mendapat persetujuan bersama. Meskipun demikian, keseimbangan kekuasaan antara legislatif, eksekutif, dan yudikatif, lebih mengemuka dibanding UUD 1945 sebelum amandemen. Pola keseimbangan tersebut terlihat fungsi pengawasan DPR yang dapat menuntut Presiden dalam siding Mahkamah Konstitusi (MK), apabila dalam hasil pengawasan, menurut DPR, Presiden telah melanggar hukum. Apabila tuntutan DPR dikuatkan oleh MK, maka DPR dapat mengajukan ke MPR sebagai lembaga yang berwenang memberhentikan Presiden sebagai tindak lanjut atas keputusan MK dan sebaliknya apabila MK menolak atau tidak menerima permohonan putusan atas pendapat DPR mengenai pelanggaran hukum Presiden, DPR tidak melanjutkan permohonan pemberhentian Presiden kepada MPR.

Sistem pertanggungjawaban Presiden merupakan salah satu sub sistem dari sistem ketatanegaraan yang ditujukan untuk mengontrol dan mengendalikan kekuasaan dan wewenang yang diberikan kepada Presiden agar tetap konsisten menegakkan nilainilai konstitusional sesuai dengan fungsi-fungsi kekuasaan yang diberikan kepadanya. Lord Acton dikutip oleh Firadus (2002: 141) menegaskan bahwa, "power tends to corrupt, and absolute power tends to corrupt absolutely. Oleh karena itu, berbicara tentang pertanggungjawaban terhadap kekuasaan, secara khusus pertanggungjawaban Presiden merupakan mata rantai yang tidak terpisahkan dari sistem pengawasan kekuasaan dalam paham demokrasi dan konstitusi.

Perubahan-perubahan yang melingkupi UUD 1945 pasca reformasi merupakan jawaban atas pemikiran tentang sistem ketatanegaraan di bawah UUD 1945 yang dianggap belum dapat membangun demokrasi dan pemerintahan yang bertangung jawab. Tidak dapat dipungkiri bahwa salah satu agenda besar di balik amandemen UUD 1945 adalah upaya membangun sistem ketatanegaraan dalam kerangka demokrasi dan supremasi hukum. Dengan demikian, untuk menelaah sistem, bentuk, dan prosedur pertanggungjawaban Presiden setelah amandemen UUD 1945, tidak terpisahkan dengan konstruksi demokrasi dan konstitusi setelah amandemen UUD 1945, yang mana menurut Firdaus elemen-elemennya adalah sebagai berikut: 1) Konstruksi Demokrasi Dan Implikasinya Terhadap Pertanggugjawaban Presiden; 2) Kekuasaan Presiden sebagai Lingkup Pertanggungjawaban; 3) Tindakan Presiden sebagai Kausa Pertanggungjawaban; 4) Cara Pengisisan Jabatan Presiden dan Implikasinya terhadap Pertanggungjawaban Presiden; dan 5) Pertanggungjawaban Presiden sebagai Pribadi Jabatan.

Bentuk pertanggungjawaban Presiden berdasarkan pada konstitusi dapat dilihat melalui ketentuan dalam Pasal 7A. sekalipun tidak ada terminologi pertanggungjawaban dalam pasal tersebut, dapat disimpulkan bahwa ketentuan Pasal 7A merupakan pasal khusus untuk meminta pertanggungjawaban Presiden dalam bentuk pemberhentian dari jabatan dengan beberapa kualifikasi pertanggugnjawaban antara lain; pertama, pelanggaran hukum beupa pengkhianatan terhadap Negara, korupsi, penyuapan, tindak pidana berat lainnya, atau perbuatan tercela (misdemeanors); kedua, tidak lagi memenuhi syarat sebagai Presiden; ketiga, pertanggungjawaban jabatan.

Pasca amandemen UUD NRI Tahun 1945 ada indikasi untuk mengubah sistem pemerintahan menjadi Presidensil murni, dari sistem quasi Presidensil. Hal ini terlihat pada UUD (UUD yang lama) 1945 sebelum amandemen dari Pasal 1 ayat 2 UUD 1945 menegaskan "kedaulatan adalah ditangan rakyat dan dilakukan sepenuhnya oleh MPR" E-ISSN: 2657-0300 Lembaga Penelitian dan Penerbitan Hasil Penelitian Ensiklopedia $\quad 91$ 
ketentuan tersebut menyebabkan Presiden harus tunduk dan bertanggung jawab kepada MPR sebagai lembaga tertinggi Negara. Walaupun dalam kenyataannya kedudukan MPR justru tergantung kepada Presiden.

Sifat quasi atau sistem Presidensil yang tidak murni tersebut diubah ketika pada tahun 1999 hingga tahun 2002 UUD dilakukan amandemen, yaitu dengan mengubah kedudukan MPR tidak lagi sebagai lembaga tertinggi Negara, melainkan sebagai lembaga Negara yang sederajat dengan Presiden. Apalagi Presiden dan wakil Presiden dipilih secara langsung, pada tahun 2004 sebagai laboratorium pertama demokrasi pemilihan langsung, merupakan realisasi dari Pasal 22 E ayat 2 UUD NRI Tahun 1945 "pemilihan umum diselenggarakan untuk memilih anggota Dewan Perwakilan Rakyat, Dewan Perwakilan Daerah, Presiden dan wakil Presiden dan Dewan Perwakilan Rakyat Daerah (perubahan ketiga UUD NRI tahun 194510 November 2001)" berarti jabatan Presiden dan wakil Presiden sangat kuat (strong) karena dipilih oleh rakyat secara langsung dan pertanggungjawabannya juga kepada rakyat.

Ini menunjukan bahwa Presiden tidak dapat dijatuhkan oleh parlemen melalui sidang paripurna MPR saja, seperti pemberhentian Abdul Rahman Wahid oleh parlemen. Kedudukan (jabatan) Presiden sedemikian kuat, hingga pengawasannya hanya ada pada DPR. Yang mana DPR sewaktu-waktu dapat melakukan hak interpelasi dan hak angket kepada Presiden, dalam rangka pemakzulan Presiden. Itupun Presiden hanya dapat diberhentikan melalui usul DPR apabila terbukti melakukan pelanggaran hukum berupa penghianatan terhadap Negara, korupsi, penyuapan tindak pidana berat lainnya, atau perbuatan tercela maupun apabila tidak lagi memenuhi syarat sebagai Presiden dan wakil Presiden.

Melakukan pemakzulan (impeachment) terhadap Presiden tidak segampang dulu, pengajuan permintaan DPR dalam rangka impeachment Presiden dengan dukungan sekurang-kurangnya $2 / 3$ dari jumlah anggota DPR yang hadir dalam sidang paripurna yang dihadiri oleh sekurang-kurangnya $2 / 3$ dari jumlah anggota DPR. Jika koalisi partai pemerintah di parlemen kuat berarti tidak dengan gampang juga pengajuan impeachment ke MK untuk diputuskan kemudian oleh MPR dalam rangka pemberhentian secara politik (keputusan politik). Dengan demikian pasca-amandemen UUD NRI 1945, sistem pemerintahan yang dianut adalah Presidensil dengan prinsip check and balance.

\section{Penutup}

Melihat sistem pertanggungjawaban dalam konstitusi Republik Indonesia dapat dikatakan mengarah kearah pranata impeachment, yaitu meminta pertanggungjawabab Presiden karena adanya dugaan pelanggaran hukum. Sehingga dapat dikatakan bahwa bentuk pertanggungjawbaannya adalah pertanggungjawaban hukum. Namun, tidak tertutup kemungkinan adanya pertanggungjawaban politis, berupa laporan Presiden kepada DPR sehubungan dengan fungsi pengawasannya. Tetapi pertanggungjawaban politik ini tidak mengancam kedudukan Presiden, dengan kata lain Presiden tidak dapat dijatuhkan karena alasan politik. Hal ini merupakan salah satu ciri sistem presidensil. Sedangkan pertanggungjawaban Presiden kepada rakyat secara langsung hanya merupakan pertanggungjawaban moral. Diterima atau tidaknya pertanggungjawaban Presiden oleh rakyat dapat dilihat dari kesetiaan rakyat untuk tetap memilihnya di pemilihan selanjutnya apabila Presiden terpilih bersangkutan mencalonkan diri kembali. 


\section{Daftar Pustaka}

A. Ahsin Thohari, Komisi Yudisial dan Reformasi Peradilan, Elsam, 2004

A. Hamid S. Attamimi, Peranan Keputusan Presiden Republik Indonesia dalam Penyelenggaran Pemerintahan Negara; Suatu Studi Analisa Mengenai Keputusan Presiden yang Berfungsi Pengaturan dalam Kurun Waktu Pelita IPelita IV, Disertasi, Fakultas Pascasarjana UI, 1990

Firdaus, Pertanggungjawaban Presiden Dalam Negara Hukum Demokrasi, Yrama Widya, Bandung, 2007

J.J. von Schmid, Pemikiran Tentang Negara dan Hukum, Pembangunan, Jakarta, 1988 Jimly Asshidiqie, Presidensial Versus Parlementarisme, dalam Gerak Politik yang Tertawan Menggagas Ulang Prinsip-Prinsip Lembaga Kepresidenan, CPPS, Jakarta, 2002

Jimly Asshidiqie, Gagasan Kedaulatan Rakyat dalam Konstitusi dan Pelaksanaannya di Indonesia, Ichtiar Baru van Hoeve, Jakarta, 1994, L. Said Ruphina, Menggagas Formal Ideal antara Lembaga Kepresidenan dengan Lembaga Tinggi Negara Liannya, dalam gerak politik yang tertawan: Menggagas ulang prinsip-prinsip Lembaga Kepresidenan, CPPS, Jakarta, 2002

Moh Mahfud, Dasar dan Struktur Ketatanegaraan Indonesia, Rineka Cipta, Yogyakarta, 2001

Miriam Budiardjo. Dasar-Dasar Ilmu Politik.: Gramedia Pustaka Utama, Jakarta, 2005

Rahimullah, Hukum Tata Negara; Hubungan Antar Lembaga Negara, PT. Gramedia, Jakarta, 2007

S.F. Marbun, Negara Hukum dan Kekuasaan Kehakiman, Jurnal Hukum Ius Quia Iustum, No. 9 Vol 4 - 1997

Sobirin Malian, Gagasan Perlunya Konstitusi Baru Pengganti UUD 1945, FH UII Press, Yogyakarta, 2001

http://www.hukumonline.com/berita/baca/hol1301/memintapertanggungjawabanpresiden $21 / 5 / 14$

http://dorisfebrianda.blogspot.com/2013/04/sistim-pembagian-kekuasaan-negara.html. 